\title{
BIOSTUDIO: SERES VIVOS, TECIDOS E INOVAÇÃO
}

\section{BIOSTUDIO: LIVING BEINGS, FABRICS AND INNOVATION}

\section{Breno Abreu, M.Sc. (UnB) \\ Christus Nóbrega, Dr. (UnB)}

\author{
Palavras Chave \\ Biodesign; Tecido; Tingimento; Bactéria
}

\section{Key Words}

Biodesign; Fabric, Dyeing; Bacteria

\section{RESUMO}

O Biodesign talvez seja uma das maiores alternativas na contemporaneidade para se repensarem processos produtivos da cadeia têxtil, recriando desde o próprio tecido a processos de beneficiamento. A presente pesquisa faz um levantamento dos estudos recentes relacionados à utilização de seres vivos na fabricação de artigos têxteis e exemplifica por meio de um experimento de tingimento em tecidos orgânicos utilizando bactérias, que além de repensar o processo, renova a estética do design de superfície atual.

\section{ABSTRACT}

Biodesign is perhaps one of the greatest alternatives in contemporaneity to rethink manufacturing processes of the textile chain, recreating from the fabric itself to processes of beneficiation. The present research is a survey of recent studies related to the use of living beings in the manufacture of textile articles and exemplifies through an experiment of dyeing organic fabrics using bacteria, which in addition to rethinking the process, renew the aesthetics of the current surface design. 


\section{INTRODUÇÃO}

A cada dia somos surpeendidos com notícias impressas e de vídeos mostrando como é possível repensar nossa forma de produção de produtos utilizando metodologias naturais de fabricação, como tingimentos com corantes provenientes de plantas e tecidos de origem orgânica vegetal ou de microorganismos.

Esses veículos sinalizam uma nova vertente de criação baseada não mais em produtos sintéticos e que vão muito além da tecnologia digital e da informatização, em uma união entre a biologia e o design.

O design é originalmente uma área interdisciplinar, alinhando e interagindo conhecimentos com áreas como a sociologia, a engenharia e a arquitetura para o desenvolvimento de novos produtos. Já a biologia, por inúmeras vezes se utiliza do design para demonstrar estruturas recriando modelos e representações de estruturas moleculares e reações.

Essa relação não é nova, uma vez que desde o renascimento paramos para observar a natureza e utilizar dos seus conhecimentos para a criação de novos produtos. Essa relação vai muito além de uma análise formalista, onde podemos observar a natureza e fazer analogias para a elaboração de produtos e sistemas, com o objetivo de encontrar soluções adequadas, sustentáveis e inesperadas para determinados projetos (LACERDA; SORANSO; FANGUEIRO, 2012).

Os laços entre biologia e design têm se estreitado e originou recentemente o termo Biodesign, utilizado para caracterizar projetos de design que fazem uso de organismos vivos como parte constituinte de produtos e serviços, ou que os utilizam no processo produtivo, agregando a tecnologia de ponta da natureza à procura de soluções para a vida contemporânea (MYERS, 2012).

Uma das grandes vantagens do Biodesign, segundo Lasky (2013) é que os produtos criados não são descartados, eles são reabsorvidos pelo meio ambiente no ciclo de nutrientes da natureza.

A presente pesquisa tem como objetivo destacar alguns projetos na área de Biodesign que utilizam seres vivos nos processos produtivos do desenvolvimento têxtil, assim como exemplificar a temática por meio de um experimento realizado de tingimento de tecidos orgânicos utilizando bactéria e ainda demonstrando seus desdobramentos estéticos no design de superfície.

A relevância desse tema está na possibilidade do desenvolvimento de novos materiais e formas de fabricação e beneficiamento de tecidos utilizando organismos vivos ou produtos provenientes da produção celular, um tipo de pesquisa quase inexistente no Brasil. Já a escolha da bactéria para a parte experimental deu-se devido à boa relação que temos com estes microrganismos desde a antiguidade, e especificamente a actinobactéria por ser não patogênica, facilmente encontrada no solo, produzir pigmento e ter um crescimento relativamente rápido.

A pesquisa apresenta assim um caráter interdisciplinar e fará uso de uma metodologia própria e flexível, em alguns momentos exploratória e descritiva, com análise de dados qualitativos. Esta flexibilidade é necessária devido ao caráter multidisciplinar do projeto, reunindo instrumentos metodológicos adequados de cada uma das áreas.

Como procedimentos, estão: revisão bibliográfica, estudos de caso e observações e experimentos com a actinobactéria em laboratório. A técnica de pesquisa será uma documentação direta, intensiva e observação sistemática em laboratório que será descrita ao longo dos tópicos que dissertam a respeito dos experimentos executados. Todas as etapas foram registradas em um livro ata, de utilização comum a cientistas na realização de experimentos, mas com registros fotográficos.

Os tópicos deste artigo serão divididos de acordo com a metodologia e realização dos experimentos que apresentarão o material e métodos e os resultados conjuntamente e por último as considerações finais irão relacionar e tecer uma trama de questionamentos para experimentos e possibilidades futuras.

\section{REFERENCIAL TEÓRICO}

A relação do homem com a natureza sempre existiu, mas teve sua abordagem e observação de uma forma mais precisa no período do Renascimento, marcado por grandes descobertas científicas e com grandes avanços para a humanidade, sendo um dos seus grandes entusiastas Leonardo da Vinci (1452-1519), que empregou com maestria muitas de suas análises em seus projetos de arquitetura e desenvolvimentos de produtos.

Já no período do Art Nouveau, no final do século XIX, a natureza foi mais uma vez evocada em criações que utilizavam as formas naturais como inspiração formal, e que pôde ser viabilizada devido ao ascendente desenvolvimento da indústria como um todo, possibilitando a utilização de novas matérias primas. Destacam-se nesse período, tanto no design quanto na arquitetura, as figuras de Gustav Klimt (1862-1918) e Antoni Gaudi (1852- 1926).

A replicação de formas da natureza no design de produtos e estruturas acontece há anos e marcou o século XIX, principalmente com o Art 
Nouveau. Essa abordagem do design regido pela forma faz referência à natureza utilizada como efeito metafórico, simbólico ou decorativo. (MYERS, 2012, p.11)

A partir da década de 50, no entanto, uma nova revolução alteraria nossa configuração social e industrial, a revolução trazida pela informatização. Novas formas de pensar e produzir foram inventados e com isso, custos com ferramentas e fabricação foram cada vez mais barateados e os custos com planejamento, preparação e codificação, onde se encontra o trabalho do designer, foram em muito valorizados.

Já na contemporaneidade, segundo Dubberly (2008), a biologia tem feito grandes descobertas, como os organismos fazem codificação, armazenagem, reprodução, transmissão do DNA e mapeamento de rotas de sinalização celular, indicando que a biotecnologia dominará a cena atual, assim como a tecnologia teve e tem destaque desde 1950.

Analisando a relação entre design e biologia nesse contexto, percebe-se que as duas áreas compartilham um foco em como se dá o fluxo da informação, com a rede realizando diferentes trocas, sendo necessária para um equilíbrio entre as comunidades, assim como ocorre na natureza. $A$ interação entre as áreas tem buscado outros compromissos não tão científicos como também poéticos.

A observação da natureza com a finalidade de fazer analogias formais e funcionais foi estabelecida como método Biomimético em 1957, termo utilizado pela primeira vez por Otto $\mathrm{H}$. Schmidt para caracterizar justamente a busca de soluções para problemas humanos por meio da observação da natureza. (LACERDA; SORANSO; FANGUEIRO, 2012).

Janine Benyus (2012), fundadora do Biomimicry Institute, divide a biomimética em três áreas de estudo: a natureza como modelo, a natureza como medida, e por fim, a natureza como mentora. A autora justifica o seu processo de inspiração pela natureza principalmente devido à evolução e a seleção natural, onde se pode aproveitar de uma sabedoria construída há 3,8 bilhões de anos, desde a primeira bactéria.

Assim como Benyus, Frosch (1989) propõe que o processo industrial pode ser planejado como um ecossistema, onde toda sobra se torna matéria prima para outro processo, possibilitando assim processos mais naturais e sustentáveis.

Para obter um desempenho ecológico, designers têm procurado integrar sistemas naturais, aliando seu trabaIho ao conhecimento e a experiência dos biólogos. Essa integração, obviamente, não trará soluções imediatas para os problemas e deverá ser uma pesquisa exploratória, com alguns trâmites éticos. (BENYUS, 2012).

Pensando-se em uma relação mais próxima entre os seres vivos e os produtos, uma possibilidade é ao invés de utilizar o Ser como inspiração, é utilizá-lo no processo de fabricação ou na constituição do próprio produto. Assim surge o conceito de Biodesign onde para Antonelli (2012), a proposta é utilizar tecidos vivos, sejam culturas de tecidos ou plantas, e materializar o sonho do design orgânico: observar o objeto se desenvolver e depois, deixar ao encargo da natureza tomar conta do restante.

Antonelli (2012) acredita que as consequências e lançamentos provenientes destes projetos, será uma nova forma de fazer e pensar design, além de mudanças na trajetória do homem, e passagem da era da informática para a era da biologia. Pode ainda servir para atender a demanda de tecnologias mais limpas e a possibilidade do usuário criar produtos sem sair da sua casa. Criar e construir projetos utilizando bactérias e outros organismos vivos tem se tornado uma necessidade e uma possibilidade tecnológica.

\section{ESTUDO DE CASO}

Com o intuito de demonstrar algumas pesquisas que estão sendo realizadas na área do Biodesign e sua relação com a indústria têxtil, foram selecionados alguns projetos práticos e conceituais para serem analisados.

Um dos mais importantes projeto de Biodesign, BioCuture (2011), foi criado por Suzanee Lee na Central Saint Martins College of Art and Design, de Londres. A pesquisa investiga como microrganismos podem ser utilizados para originar um biomaterial para a indústria têxtil.

Para a realização de seu experimento, Lee utiliza uma colônia simbiótica formada por levedura e uma bactéria denominada Gluconacetobacter xylinum. Essa colônia é popularmente conhecida como Kombucha, e é consumida como fermentadora de uma bebida à base de chá. Para a criação do tecido, um chá verde concentrado é preparado com a adição de grande quantidade de açúcar e vinagre orgânico de maçã, colocado em um recipiente de plástico ou vidro. A cultura é adicionada ao chá e conservada tampada com tecido respirável à aproximadamente $25^{\circ} \mathrm{C}$ durante duas a quatro semanas. Após esse período, a colônia cresce, flutua e ocupa toda a área superficial do recipiente, chegando à espessura de aproximadamente dois centímetros. A colônia é então retirada do chá, lavada e colocada para secar. Após seca, a colônia/tecido está pronta para o corte e confecção da roupa. 
Durante esse processo, os microrganismos presentes na colônia produzem microfibras por meio da quebra da celulose do chá, formando essa camada flexível que origina o tecido. No geral, o tecido resultante apresenta cor amarelada, textura semelhante a um couro, possível de ser costurado. Este tecido permite ainda a estamparia com utilização de frutas e ainda o tingimento (Figura 01).

Figura 01: Cultura de Kombucha e casaco produzido a partir do material estampado
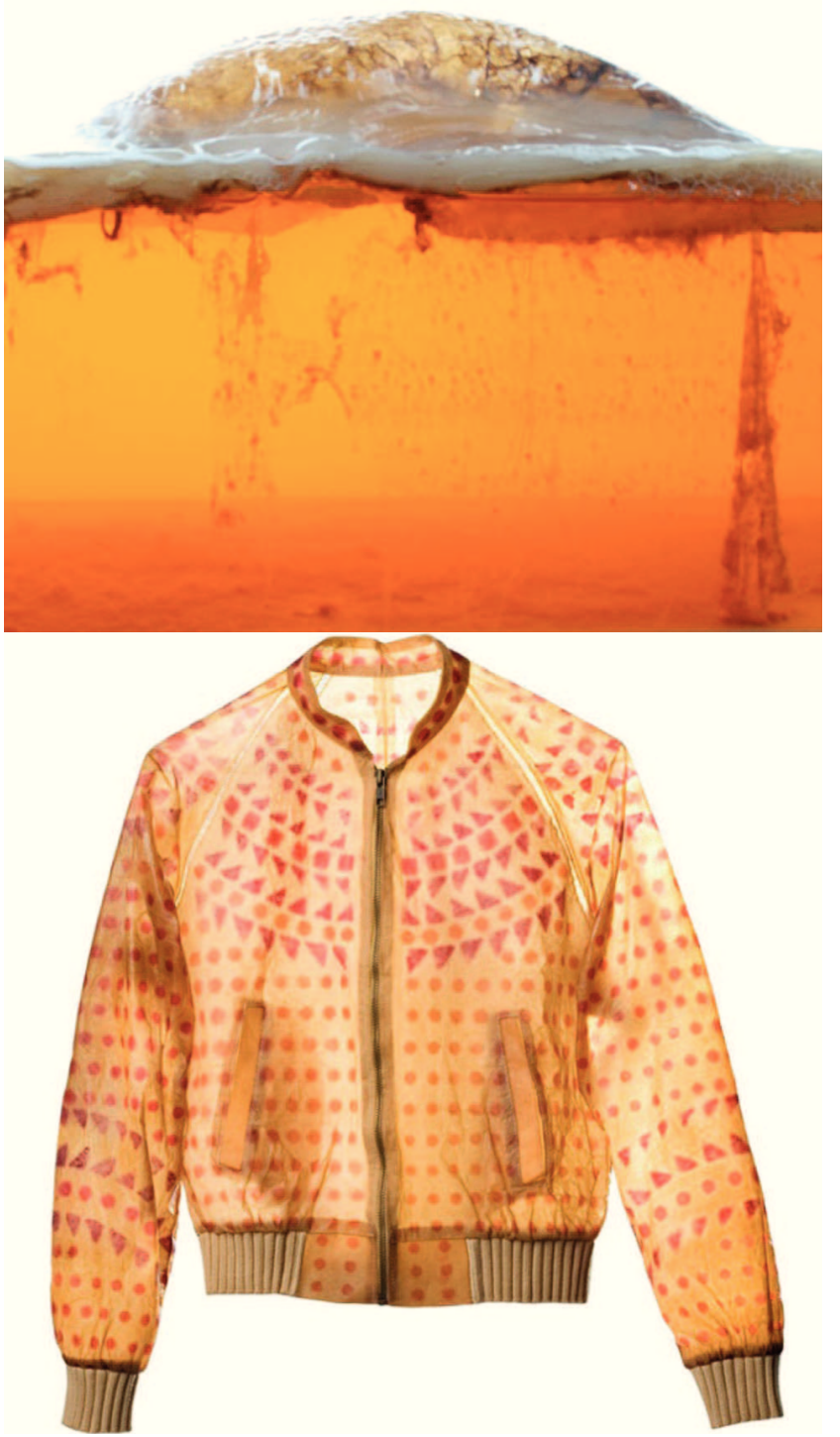

Fonte: Dezeen (2014)

O tecido resultante da criação de Lee é uma excelente proposta de utilização de biomaterial por ser inteiramente sustentável e ter uma produção relativamente fácil que poderia ser realizada pelo próprio usuário. Sua visão possibilitou a visualização de um processo de produção de chá, como um processo de criação de tecido e esse seu novo olhar também é uma das grandes contribuições de seu trabalho para os pesquisadores de design, que deveriam rever processos de fabricação clássicos e artesanais como uma possibilidade de emprego em projetos futuros.

Outro projeto de grande valia na produção de fios de origem animal é a "seda marinha" produzida por um dos maiores moluscos bivalves nativos do mar mediterrâneo, o Pinna nobilis. Raras são as pessoas na atualidade que se dedicam a coleta da saliva deste mexilhão que apresenta característica dourada.

Essa seda natural chamada bisso é fina, leve e resistente à água e álcool, mas que precisa de um tratamento específico para ser lavada e fiada de forma manual. O bisso é um material nobre, mencionado inclusive na bíblia e que foi utilizado por egípicios e fenícios (Figura 02).

A italiana Chiara Vigo é uma das poucas pessoas hoje em dia capaz de coletar, tratar e tecer o fio, e faz de forma a preservar uma tradição familiar, sem fins lucrativos. Esse tipo de projeto histórico possui um valor tradicional incomensurável e demonstra outra possibilidade de utilização de técnicas tradicionais na criação de texteis.

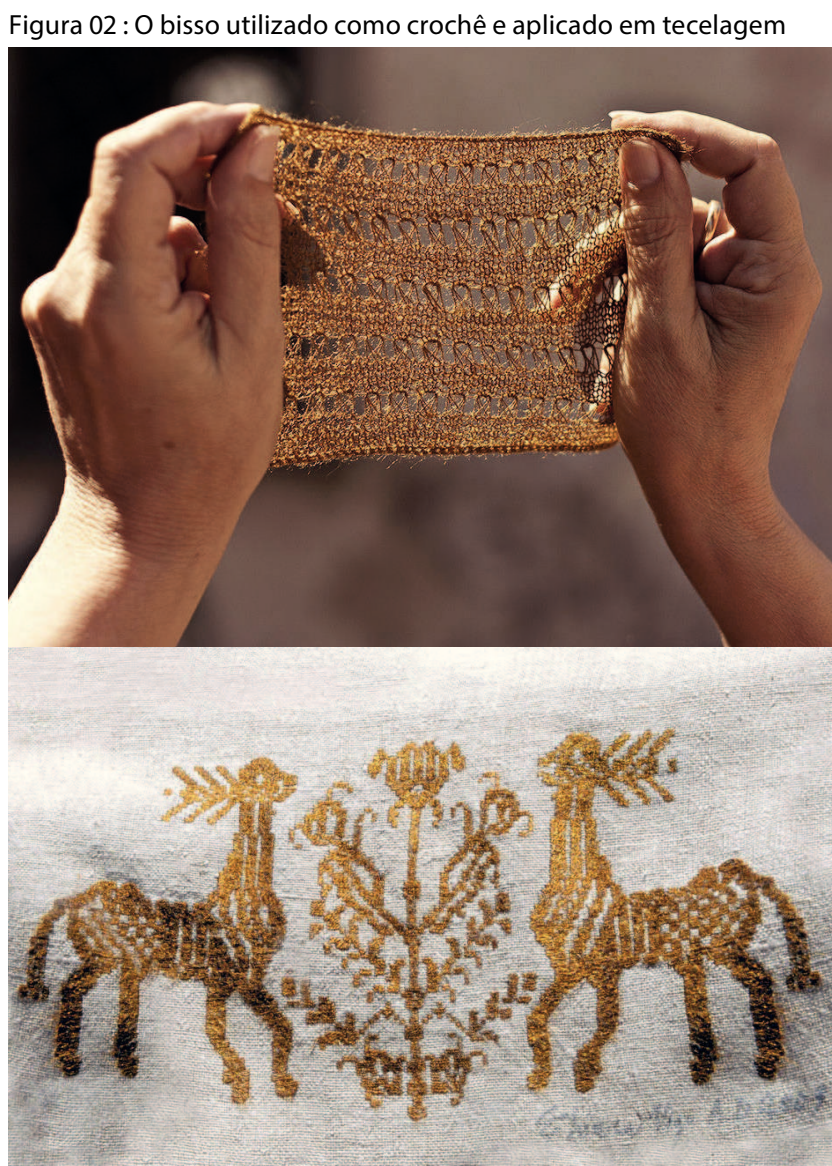

Fonte: Metamorfose Digital (2015) 
Já no projeto Victimless leather (2004), um dos mais antigos e bastante conceitual, os cientistas Catts e Zurr do laboratório australiano SymbioticA, criaram um casaco constituído por tecido celular de ratos, que permaneceu vivo durante cinco semanas alimentando-se de um bionutriente de origem animal em uma bomba peristáltica (Figura 03).

Figura 03: Casaco constituído de polímero e células de rato

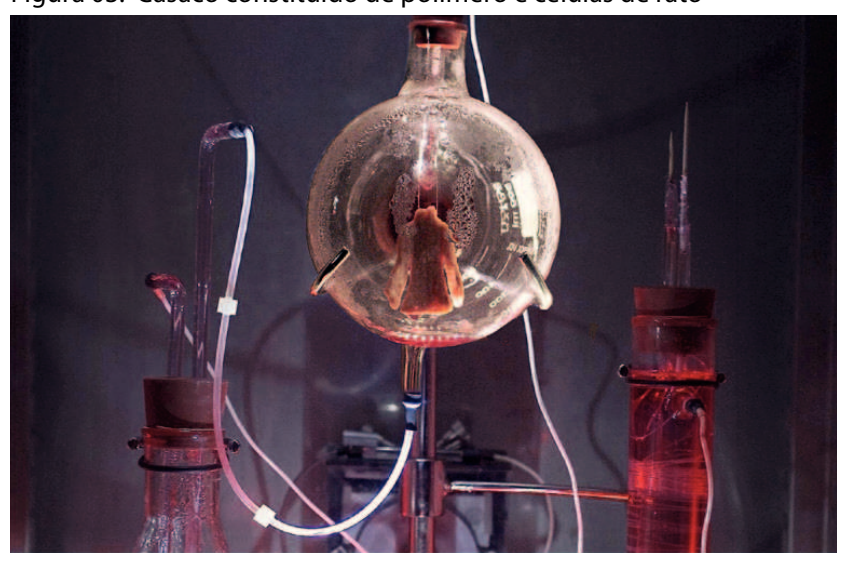

Fonte: The Tissue Culture and Art Project (2017)

A base do casaco foi criada em um polímero biodegradável e depois semeada com células ósseas e cartilaginosas de rato. Os maiores problemas encontrados pelos pesquisadores Catts e Zurr para a execução deste protótipo de casaco constituído por células de rato, foram à nutrição dos tecidos celulares formado por compostos de origem animal e a escala dos protótipos, ainda muito restrito a tamanhos pequenos.

Além dos problemas técnicos encontrados, claramente este tipo de pesquisa envolve também alguns questionamentos éticos em relação à pesquisa, mas que devem ser discutidos.

Algumas outras vertentes de projetos não tão polêmicos foram criados recentemente desenvolvendo couro de boi de origem completamente artificial e produtos e tecidos que utilizam cogumelos como base para desenvolvimento de couros vegetais.

Inúmeras outras pesquisas poderiam ser citadas aqui como propostas de renovação da indústria têxtil, principalmente em relação à tingimentos naturais, que são realizados atualmente com açafrão, casca de cebola, hibisco, dentre outros. Um dos maiores investimentos na área de tingimento natural são os da antocianina, um pigmento pertencente ao grupo dos flavonoídes, costumeiramente empregado como corante alimentício de origem vegetal e que tem uma variabilidade cromática (laranja,vermelho, rosa e roxo), que tem sido prospectado para a coloração de fibras têxteis. Ficam aqui então esses indícios que motivaram o desenvolvimento do presente trabalho e que serve como inspiração para muitos outros.

\section{TINGIMENTO COM BACTÉRIAS}

Segundo SILVA (2001), o tingimento de tecidos é uma prática que existe há milhares de anos. A tecnologia atual de tingimento consiste de muitas etapas e que são escolhidas de acordo com a natureza da fibra têxtil, características estruturais, classificação e disponibilidade de corante, fixação compatível com o destino do material a ser tingido, preço, dentre outros. Durante o tingimento, a fixação do corante, a proporção da quantidade de água e a necessidade de aquecimento são críticos durante esse processo. Um ideal de sustentabilidade seria usar um corante que requeresse menor quantidade de água, alta fixação, diminuindo a quantidade de químicos auxiliares no processo de tingimento e a ausência de aquecimento, minimizando a energia gasta no processo. Seria de grande valia também, produzir um corante que pudesse ser reutilizado, e quando esgotado, fosse descartado na natureza sem causar danos.

Com o foco nesta proposta de corante, chegou-se a possibilidade de um corante originado a partir de bactérias, onde o inóculo/coloração de um tecido serviria como início/inóculo de outra arremessa de tecido, e quando finalizada a coloração, o material descartado poderia servir como fertilizante para plantações, não havendo desperdícios e nem descartes indevidos. Assim pesquisou-se uma possível bactéria produtora de pigmento que pudesse ser utilizada para a realização dos experimentos e foi encontrada a actinibactéria.

As actinobactérias, escolhidas para a utilização nesta pesquisa, são bactérias Gram-positivas importantes, formando um filo que compreende um grande número de microrganismos, sendo citadas mais de 30 famílias taxonômicas. As espécies têm morfologia bastante variável desde a forma bacilar até filamentosa. São predominantemente aeróbias, presentes comumente em solos e matéria vegetal. São em sua maioria inofensivas (por isso de sua escoIha para utilização em roupas) e apresentam importância econômica na produção de antibióticos e diversas enzimas entre elas as celulolíticas (MADIGAN et al., 2010).

Neste trabalho, a maior parte dos microrganismos pertence ao gênero Streptomyces que formam filamentos ramificados. Devido a sua proliferação e ramificação, esses microrganismos formam redes de filamentos denominados micélio, parecido com os micélios formados pelos fungos filamentosos. 
Uma característica importante das actinobactérias, é que elas produzem esporos quando em situações extremas, conferindo-lhe proteção, sendo justamente nessa fase produzidos pigmentos e antibióticos por estas bactérias.

Para a realização dos experimentos foram utilizadas seis linhagens de actinobactérias (G27, G28, G29, G78, G85 e JUA183) isoladas de amostras da rizosfera da Caatinga pertencentes à Coleção de Cultura de Microrganismos do Departamento de Antibióticos (UFPEDA) da Universidade Federal de Pernambuco.

O processo de isolamento (produção de cultura pura de um determinado microrganismo, onde todas as células na população sejam idênticas) de estreptomicetos do solo é feito por meio da diluição de uma amostra de solo em água estéril, diluído e inoculado em meio sólido a base de sais minerais e amido ou caseína a $25^{\circ} \mathrm{C}$. Após 5 a 7 dias, são analisadas a presença característica de colônias de estreptomicetos (MADIGAN et al., 2010).

Os estreptomicetos são pouco exigentes nutricionalmente, fazendo uso de grande variedade de fontes de carbono. São também aeróbios estritos, melhorando intensamente seu crescimento quando crescidos sob agitação. Essa característica facilita bastante a sua utilização, por poder ser crescido com um meio de cultura simples e em contato com o ar.

A seleção destas bactérias se deu justamente pelas características apresentadas acima, de produção de pigmento, produção de antibiótico, esporulação e não patogenicidade, além da temperatura de crescimento de $37^{\circ} \mathrm{C}$ e pela facilidade de crescimento em meio de cultura de simples preparo (ISP-3), com ingredientes baratos. Depois de estas actinobactérias selecionadas serem recebidas da Coleção de Microrganismos do Laboratório de antibióticos da UFPE, as linhagens preservadas foram primeiramente inoculadas (colocadas para crescer) em pré-inóculos de 50 mililitros $(\mathrm{mL})$ de meio ISP-3 líquido (60 gramas de farinha de aveia, $1 \mathrm{~mL}$ de solução de traço de sais e $1000 \mathrm{~mL}$ de água destilada, $\mathrm{pH}=7,2$ ), e cultivadas sob agitação 180 rotações por minuto (rpm) por cinco dias a $37^{\circ} \mathrm{C}$.

Primeiramente foram realizados os experimentos com a actinobactéria para testar a incorporação do microrganismo a tecidos orgânicos (algodão, seda ou linho). Foram realizados para tanto, testes em meio de cultura sólido e líquido com diferentes métodos e condições de inoculação e crescimento. Os resultados destes experimentos foram analisados por observação a olho nu e por microscopia óptica e registrados por fotografia. Após esses experimentos, os tecidos obtidos foram selecionados e submetidos à lavagem e passagem de acordo com as recomendações do fabricante dos tecidos.

Os seis isolados de actinobactéria selecionados, após realizado o pré-inóculo como mencionado anteriormente, foram inoculados com o auxílio da alça de Drigalski em placas de Petri com $90 \mathrm{~mm}$ de diâmetro preparadas de duas maneiras diferenciadas que aqui neste subcapítulo foram separados em experimento TOP e experimento SAND.

Essas nomenclaturas dos experimentos foram dadas devido ao local de inoculação do microrganismo, no topo do meio de cultura (TOP) e entre camadas de meio de cultura, como em uma espécie de sanduiche (SAND). Ambos apresentavam $20 \mathrm{~mL}$ de meio de cultura ISP-3 com 1,6\% de Ágar, um disco de tecido (cambraia) de $80 \mathrm{~mm}$ de diâmetro e uma segunda camada de meio ISP-3 com 0,7\% de Ágar.

A diferença entre os dois experimentos foi o local onde foi depositada a amostra de $100 \mu \mathrm{L}$ (microlitros) de bactéria coletada do pré-inóculo. No experimento TOP, as bactérias foram inoculadas sobre a segunda camada de meio, no topo da placa; já no experimento SAND o inóculo foi realizado sobre o tecido, entre as duas camadas de meio. A ilustração das placas dos dois experimentos pode ser vista a seguir na Figura 04.

As Placas foram crescidas durante cinco dias em estufa a $37^{\circ} \mathrm{C}$, tempo suficiente para que ocorra a esporulação e produção de corante pelas actinobactérias.

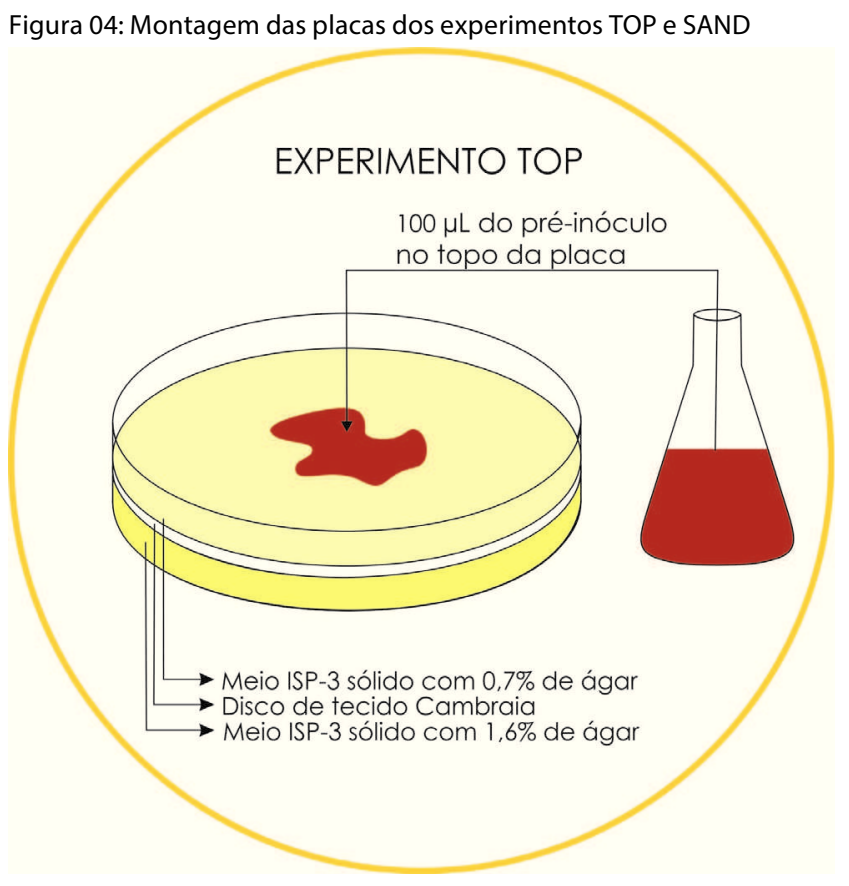




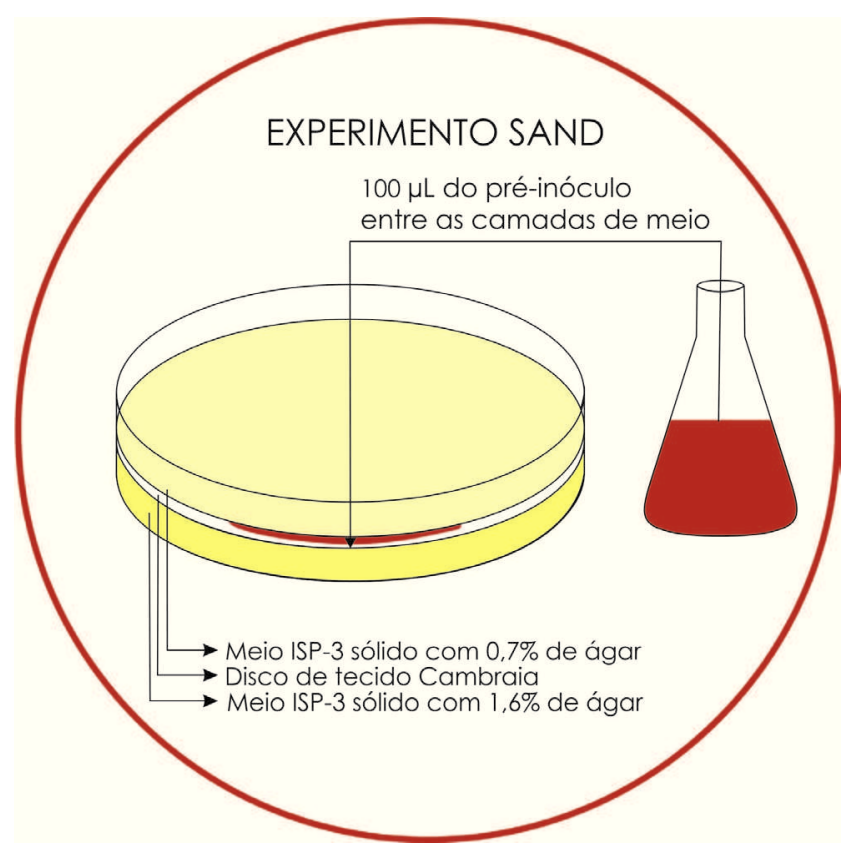

Fonte: Elaborado pelos autores.

Posteriormente, um segundo teste de coloração e interação entre as actinobactérias e o tecido foi realizada em meio de cultura ISP-3 líquido em erlenmeyers de 500 $\mathrm{mL}$. Neste experimento foi colocado dentro do frasco 100 $\mathrm{mL}$ de meio de cultura, $1 \mathrm{~mL}$ do pré-inóculo com as bactérias e um disco de cambraia de $90 \mathrm{~mm}$ de diâmetro que ficou em contato contínuo com as bactérias e o meio de cultura durante 5 dias. Esse experimento foi realizado sob constante movimentação em mesa agitadora a $180 \mathrm{rpm}$ (experimento PLAY) e estático em estufa (experimento STOP), ambos a $37^{\circ} \mathrm{C}$ (ver Figura 05).

Figura 05: Montagem dos erlenmeyers dos experimentos PLAY e STOP

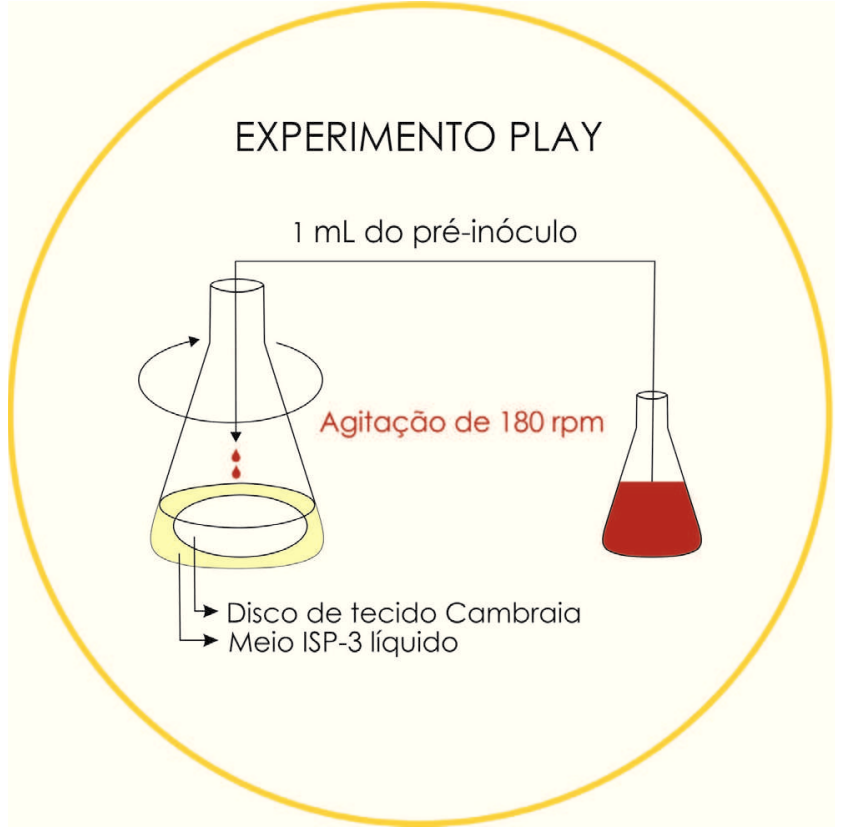

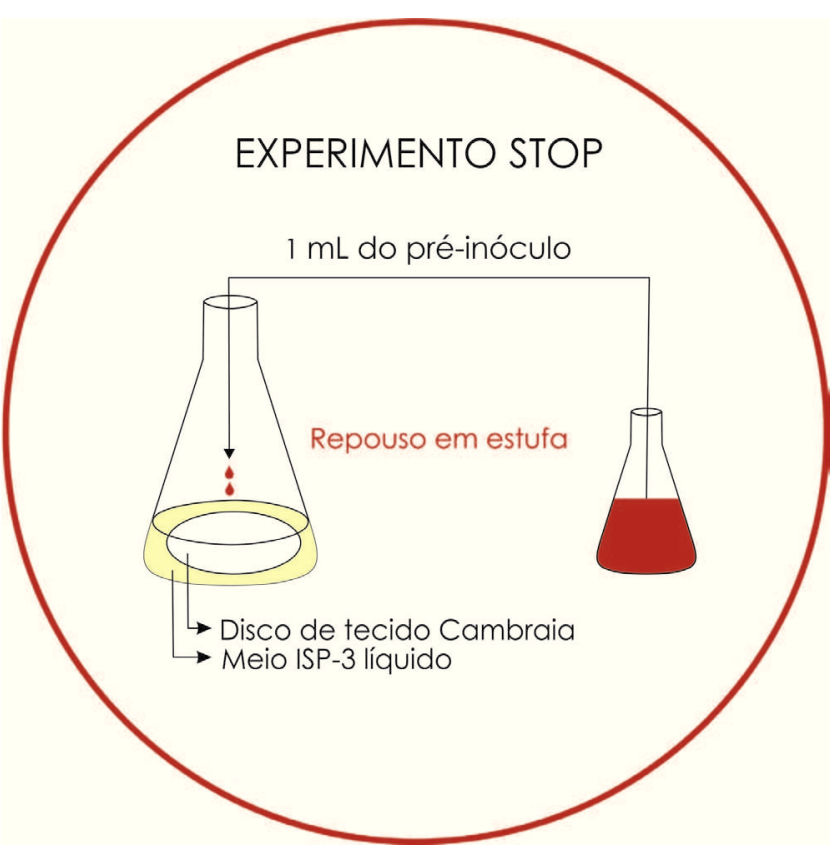

Fonte: Elaborado pelos autores.

Um último teste foi realizado em placas de Petri, mas com meio líquido em seu interior. Nas placas foram colocados o disco de cambraia com $80 \mathrm{~mm}$ de diâmetro umedecido com $10 \mathrm{~mL}$ de meio ISP-3 líquido e inoculados com $100 \mu \mathrm{L}$ do pré-inóculo. Uma preocupação com esse experimento era que o meio viesse a secar e as bactérias cessassem o seu crescimento, por isso foi adicionado um pedaço de algodão hidrofílico estéril a cada uma das placas. Além disso, $1 \mathrm{~mL}$ de meio foi adicionado as placas diariamente durante os cinco dias de crescimento em estufa a $37^{\circ} \mathrm{C}$. A este experimento demos o nome de COTTON (Figura 06).

Após a obtenção de um bom resultado com meio líquido em placas de Petri no experimento COTTON, como será demonstrado a seguir, o experimento foi repetido sem o chumaço de algodão e desta vez com diferentes tipos de tecidos de fibra natural (tricoline, laise, linho, atoalhado, seda, guipure e georgette de seda) e apenas foram utilizados dois isolados que tiveram o melhor crescimento e coloração, G27 e G85, como também será mostrado abaixo nos resultados. A quantidade inicial de meio de cultura líquido ISP-3 permaneceu a mesma, $10 \mathrm{~mL}$, e os tecidos também foram cortados em discos de $80 \mathrm{~mm}$ de diâmetro assim como no primeiro experimento. $1 \mathrm{~mL}$ de meio somente foi adicionado as placas duas vezes durante os cinco dias de crescimento, ao invés do abastecimento diário feito anteriormente. As amostras foram crescidas em estufa a $37^{\circ} \mathrm{C}$. Todos os tecidos obtidos foram submetidos à microscopia óptica para avaliação da interação entre fibra e bactéria. 


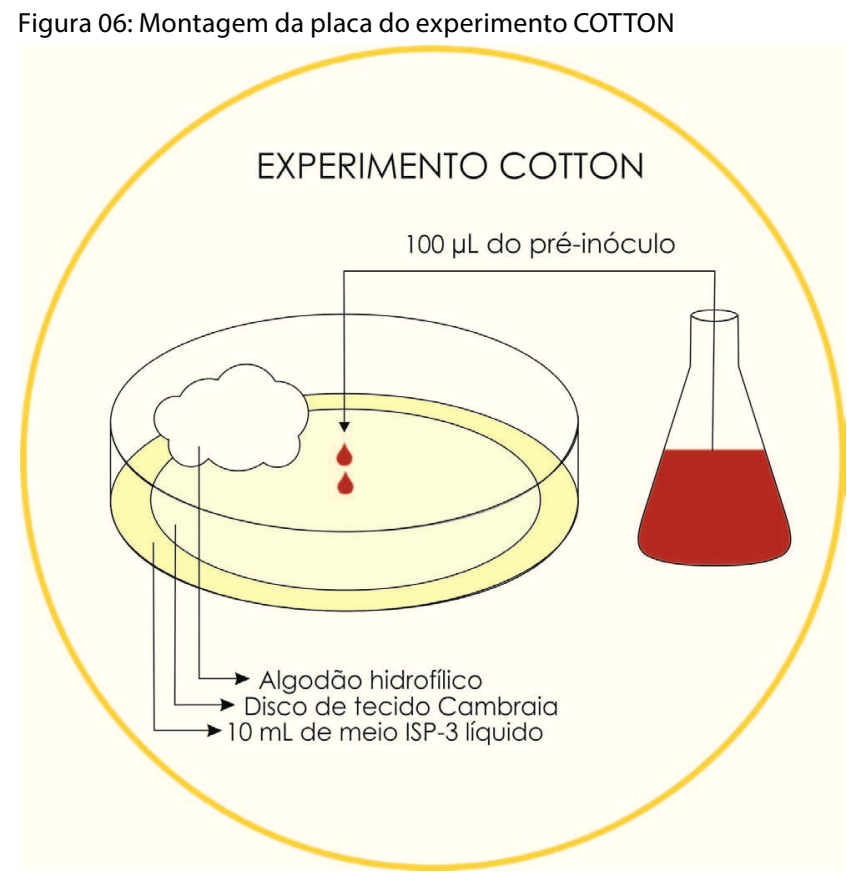

Fonte: Elaborado pelos autores.

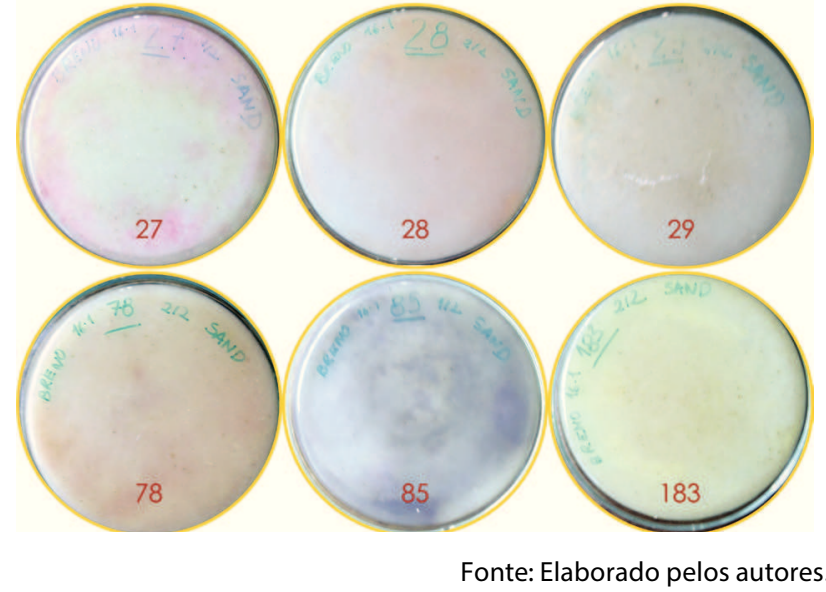

Depois de secas, as amostras do experimento TOP que obtiveram melhor resultado, não foram submetidos a nenhum processo de fixação da coloração. Esses tecidos foram cortados ao meio e uma metade submetida à lavagem durante $1 \mathrm{~h}$ em erlenmeyer contendo $100 \mathrm{~mL}$ de água destilada e $5 \mathrm{~mL}$ de detergente neutro, sob agitação de $100 \mathrm{rpm}$. As amostras lavadas foram enxaguadas em água destilada e secadas à sombra. A cor da água após a lavagem demostrou ter ocorrido grande perda de coloração do tecido para a água, no entanto os tecidos continuaram pigmentados, mas a cor ficou mais clara. Dessa forma, novas possibilidades de fixação devem ser investigadas.

Dos isolados, aqueles que pareceram ter mais perda de pigmento para a água durante a lavagem foram o G29 e o G85. De certa forma, o resultado já era esperado, uma vez que faz parte do processo de tingimento têxtil o processo de fixação do pigmento.

Já os tecidos que foram colocados em erlenmeyes e crescidos juntamente com as bactérias, com e sem agitação, caracterizando os experimentos PLAY e STOP, tiveram resultados bastante distintos entre si e dos experimentos realizados em meio sólido. Dos que cresceram sob agitação (experimento PLAY), vemos que o meio de cultura ficou muito turvo, entre os tons de amarelo e marrom, além de formarem anéis de depósito de material acima da altura do meio de cultura, além de aglomerados sobre o tecido. Pelo estudado das actinobactérias, acreditava-se de fato que esse seria o experimento com melhor sucesso de coloração.

O experimento foi então o melhor teste com resultados para a coloração do tecido cambraia de todo o laboratório de cor, onde se observou uma forte cor do pigmento, como pode ser visto na Figura 08. As colorações obtidas são as mesmas realizadas no experimento TOP, no entanto, pela figura 08 conseguimos visualizar que os 
isolados G27, G29 e G85 apresentam uma coloração bem mais escura, de alta concentração.

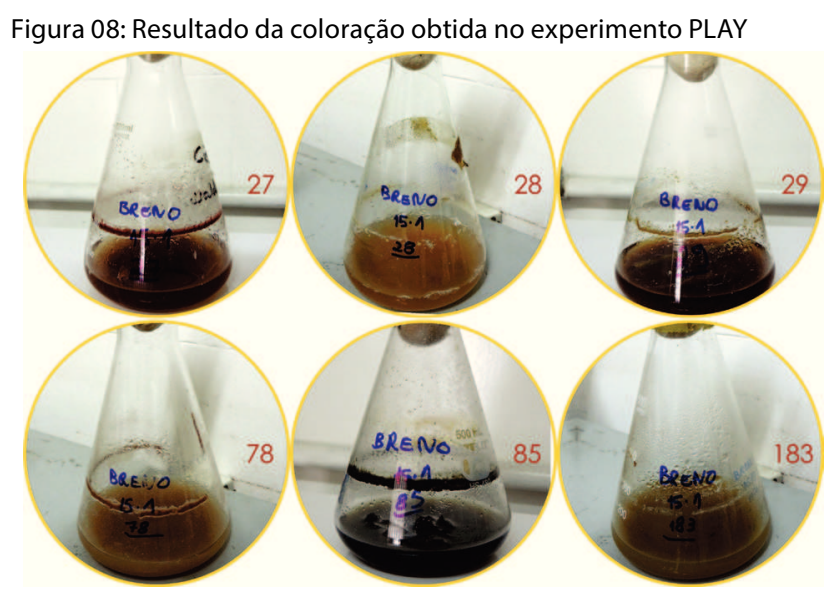

Fonte: Elaborado pelos autores.

Ao analisar o meio de cultura resultante após os cinco dias de crescimento, aparentemente esses foram os meios mais esgotados nutricionalmente, restando pouco detrito e biomassa. Por outro lado, no experimento STOP, onde as bactérias foram crescidas em meio líquido, mas em repouso em estufa à $37^{\circ} \mathrm{C}$, podemos observar outro fenômeno, o da formação de uma camada na superfície do meio de cultura de característica predominantemente esbranquiçada e com leve brilho, formada pelos esporos bacterianos e que pode ser vista mais evidentemente nos isolados G29 e G85 na Figura 09.

No entanto, apesar de aparentemente ter tido um bom crescimento, o mais importante para o resultado da pesquisa, que é o tingimento, não aconteceu de maneira eficiente no experimento STOP, muito provavelmente devido à ausência da agitação que melhora o contato entre o pigmento e o tecido, pois o meio de cultura em si, ficou corado, mas o tecido tingiu-se levemente. Comparando os experimentos PLAY e STOP é possível verificar o quanto eles são distintos somente devido à ausência de agitação e consequente aeração. É possível inferir então que, para a maior e mais eficiente produção do pigmento, é importante um bom fornecimento de oxigênio.

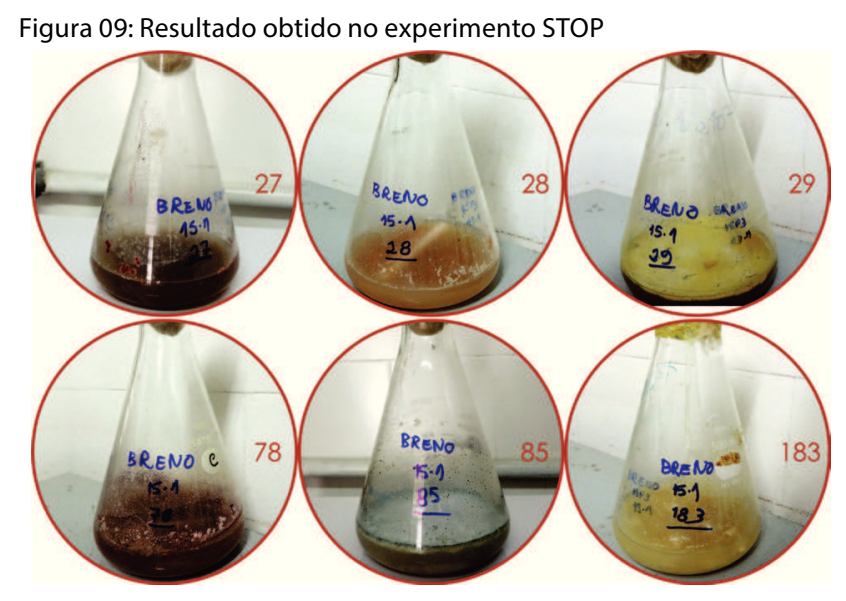

Fonte: Elaborado pelos autores.

O último teste de tingimento feito em placas de Petri, mas com meio líquido, que caracterizou o experimento COTTON, obteve um resultado mediano, pois não apresentou uma grande produção de pigmento. Além disso, verificou-se que era um experimento que precisava de ajustes, pois a quantidade de meio de cultura reposta na placa foi muito grande. Já a presença do algodão que deveria auxiliar na preservação da umidade, fez foi atrapaIhar o tingimento, pois acabava retirando os pigmentos do meio por capilaridade (Figura 10).

Figura 10: Resultado obtido no experimento COTTON

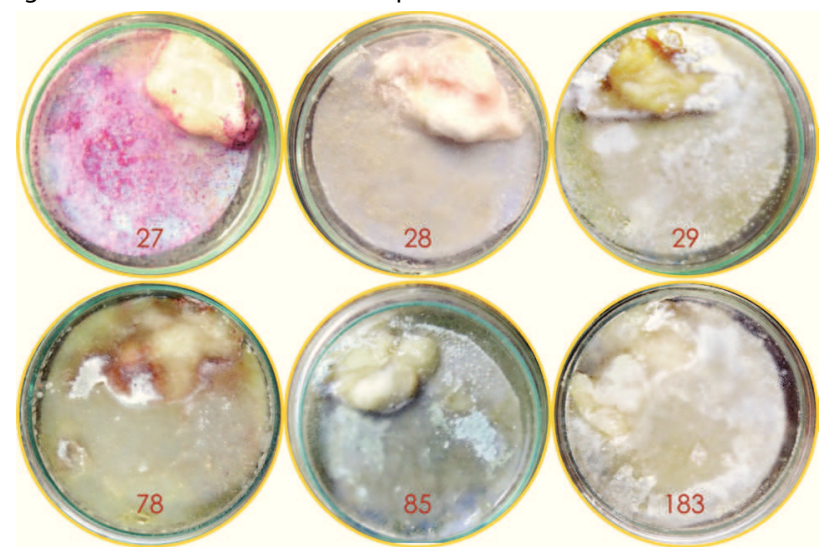

Fonte: Elaborado pelos autores.

Esses resultados dos experimentos em placa de Petri, seja com meio sólido ou líquido foram comparados utilizando-se para isso o auxílio de um contador de células, que apresenta uma lupa com aumento aproximado de $5 \mathrm{X}$ e uma luz vinda de baixo da placa, que evidencia o formato da colônia e a cor do pigmento produzido. Na figura 11 a seguir, mostra-se o quanto a coloração dos isolados G27 e G29 se sobressaem nas cores vinho e amarelo em relação aos outros isolados. Podemos ver também que a quantidade de colônias formadas foi muito maior 
no experimento TOP, do que nos experimentos SAND e COTTON. Vê-se que a coloração do fundo do tecido e do meio de cultura também é muito maior no experimento TOP do que no restante.

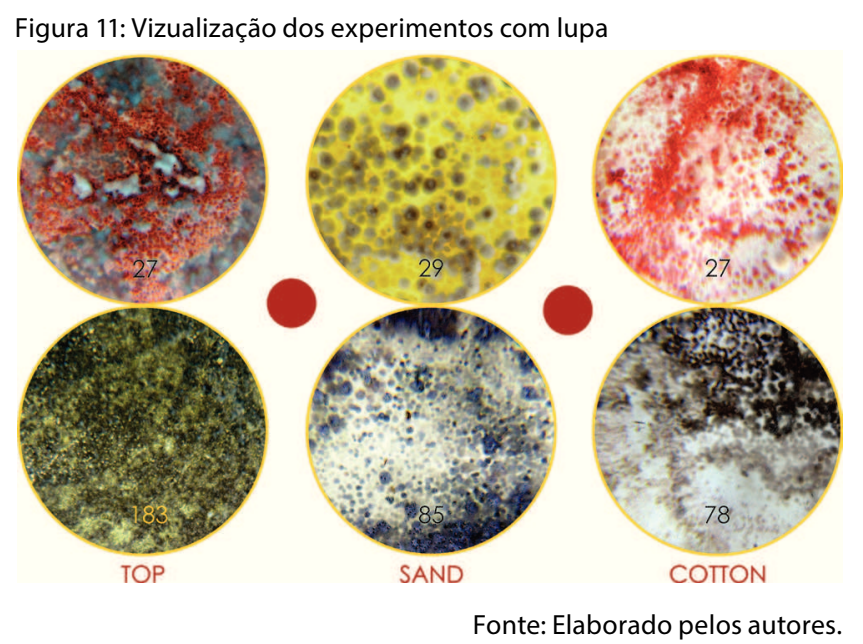

Por último o experimento COTTON foi redefinido e refeito, mas utilizando-se para isso sete tipos diferentes de tecidos de fibras naturais e apenas dois isolados que apresentaram rápido crescimento e boa pigmentação, o G27 e G85. Os ajustes no experimento com a retirada do algodão e a
No mesmo experimento, mas utilizando o isolado $\mathrm{G} 85$, temos um resultado semelhante em termos de tingimento, mas diferente em relação ao crescimento. Quando analisado o tingimento final do tecido, o linho também foi o que teve melhor coloração ao final do processo de secagem. Porém, o isolado G85 teve um excelente crescimento em todos os tecidos, transformando inclusive as texturas dos tecidos com relevo como a laise, guipure e atoalhado (Figura 13).

Figura 13: Tingimentos em diferentes tecidos pigmentados com o isolado G85

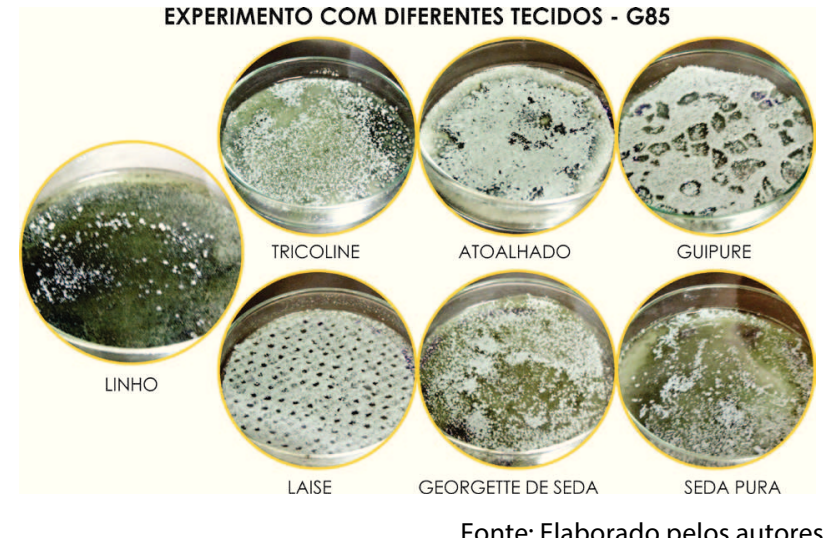

Este isolado apresenta uma esporulação intensa e muito rápida, mas que quando não está sob agitação, não produz tanto pigmento, tendo a coloração mais esverdeada do que quando em agitação, onde fica mais enegrecida.

Algumas destas amostras foram analisadas em microscopia óptica com um aumento de 200X e fotografadas para analisar a morfologia dos microrganismos. No entanto, dependendo do tecido essa visualização ficou um pouco prejudicada, principalmente nos tecidos que apresentavam fibra muito espessa, que impede a passagem da luz. Abaixo (Figura 14) podemos ver as amostras de tecido de tricoline, quanto guipure, laise e atoalhado dos isolados G27 e G85.

Figura 12: Tingimentos em diferentes tecidos pigmentados com o isolado G27.

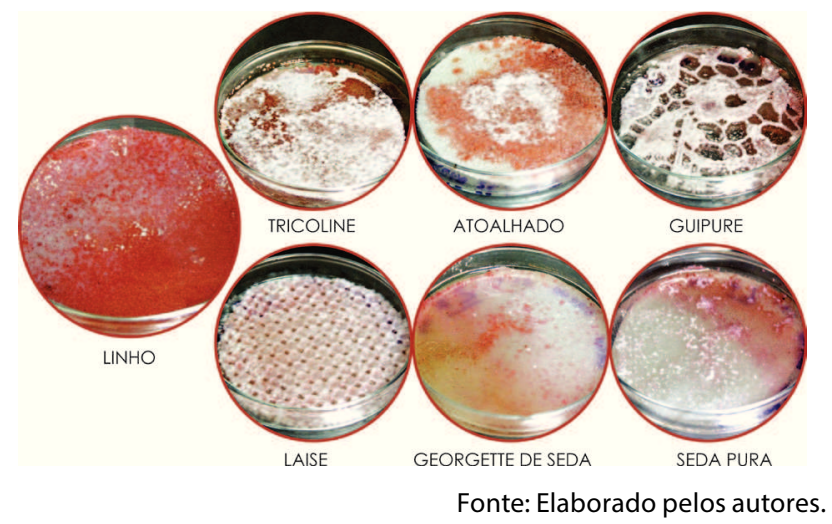


Figura 14: Análise de microscopia de diferentes tecidos com os isolados G27 e G85

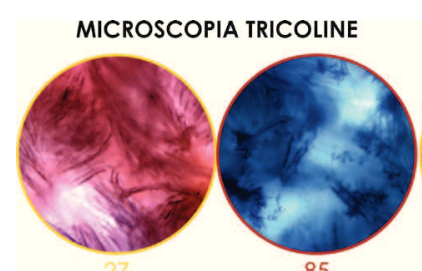

MICROSCOPIA LAISE

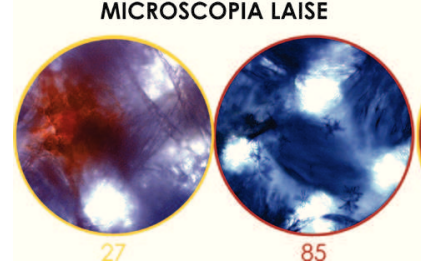

MICROSCOPIA GUIPURE

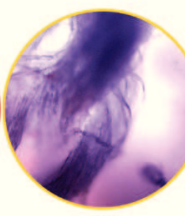

MICROSCOPIA ATOALHADO

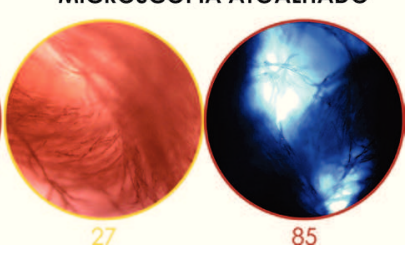

Fonte: Elaborado pelos autores.
Pode-se ver também que a localização destes isolados fica entre os fios, sendo esta uma possível região de fixação do microrganismo. Evidencia-se mais claramente a coloração avermelhada do corante do isolado G27, e apresar da coloração do isolado G85 aparecer como azulada, a cor vista no tecido a olho nu é um verde acinzentado.

A melhor forma de efetuar a coloração de tecidos orgânicos com os isolados de actinobactéria se dá por meio de crescimento líquido sob agitação, ocorrendo dessa forma uma maior produção e concentração de pigmento, além do aumento do contato do corante com o tecido.

Em relação à cor dos pigmentos produzidos, aqueles que apresentaram maior saturação foram os isolados $G 27$, G29 e G85.

O processo de lavagem mostrou que apesar dos tecidos serem possíveis serem tingidos, é necessário um processo seguinte de fixação da cor, uma vez todos perderam coloração para a água durante a lavagem.

Dos processos de tingimento em placa de Petri, o mais eficiente é a coloração aplicando-se a actinobactéria sobre o tecido. Porém nesse teste (TOP) temos uma excelente coloração apenas em um dos lados do tecido, mostrando-se assim ineficiente para utilização na indústria têxtil.

Analisando-se uma diversidade maior de amostras de tecidos, aqueles que melhor pigmentam as fibras são os constituídos de linho, seguidos pelos de algodão e seda.

Para a análise da morfologia dos isolados, a georgette de seda, por apresentar fios mais finos e espaçados, é um tecido ideal para o emprego da técnica. A tricoline também é indicada para os próximos testes, tanto pela espessura da fibra que facilita a visualização no microscópio óptico, como para verificar as estruturas celulares entre os fios de algodão do tecido.
Após a obtenção dos tecidos tingidos e fotografias do processo de produção e microscopia, uma série de estampas foram criadas digitalmente para materializar os conceitos traçados, imagens que tivessem características presentes desde a bactéria, suas cores e texturas até a raiz, física e imaterial. As primeiras estampas foram criadas a partir das fotografias de microscopia óptica dos tecidos tingidos, apresentando as próprias actinobactérias e a estrutura da trama do tecido. Essas imagens foram replicadas de forma a traçar um novo tecido, tramado digitalmente e unindo filamentos de algodão e de microrganismo (figura 15).

Figura 15: Estampas digitais criadas a partir das fotos de microscopia dos tecidos tingidos com bactérias.

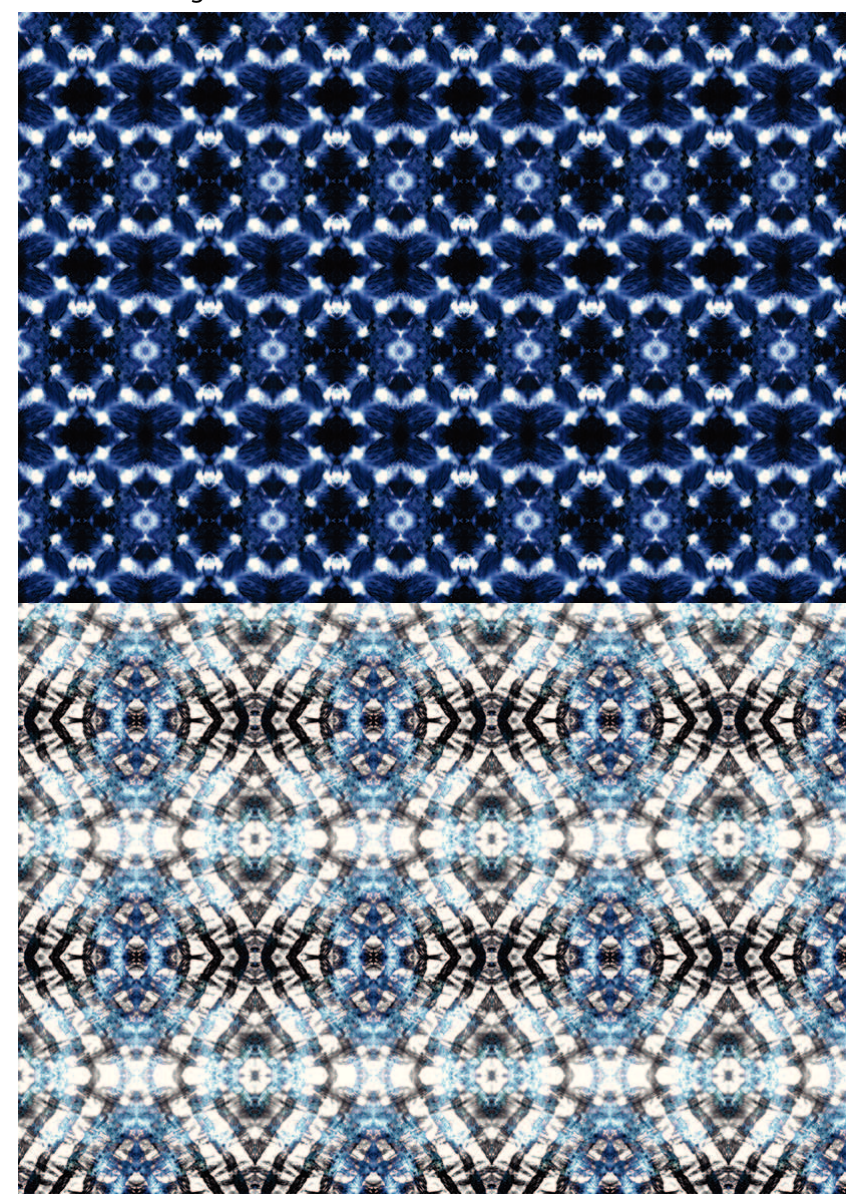

Fonte: Elaborado pelos autores.

Como o tingimento utilizando as bactérias diretamente sobre o tecido é difícil de ser controlado, a coloração dos tecidos acaba ficando não uniforme, aleatório e com aspecto manchado, bem natural e que lembra os tie dyes e batiks dos anos 70, muito utilizado pela moda do período, principalmente em uma referência ao movimento hippie. Esses manchados aparecem em quase a totalidade das estampas criadas, nas ilustrações e nas aplicações 
e estudos da forma. O manchado tem essa característica aleatória, não previsível, da proliferação das bactérias, além de ser muito mais livre e natural.

Foi também realizado um ensaio fotográfico com estas estampas reafirmando esse conceito de uma vida mais natural, mas ao mesmo tempo futurista trazida pelo conceito da biotecnologia e do biodesign (Figura 16).

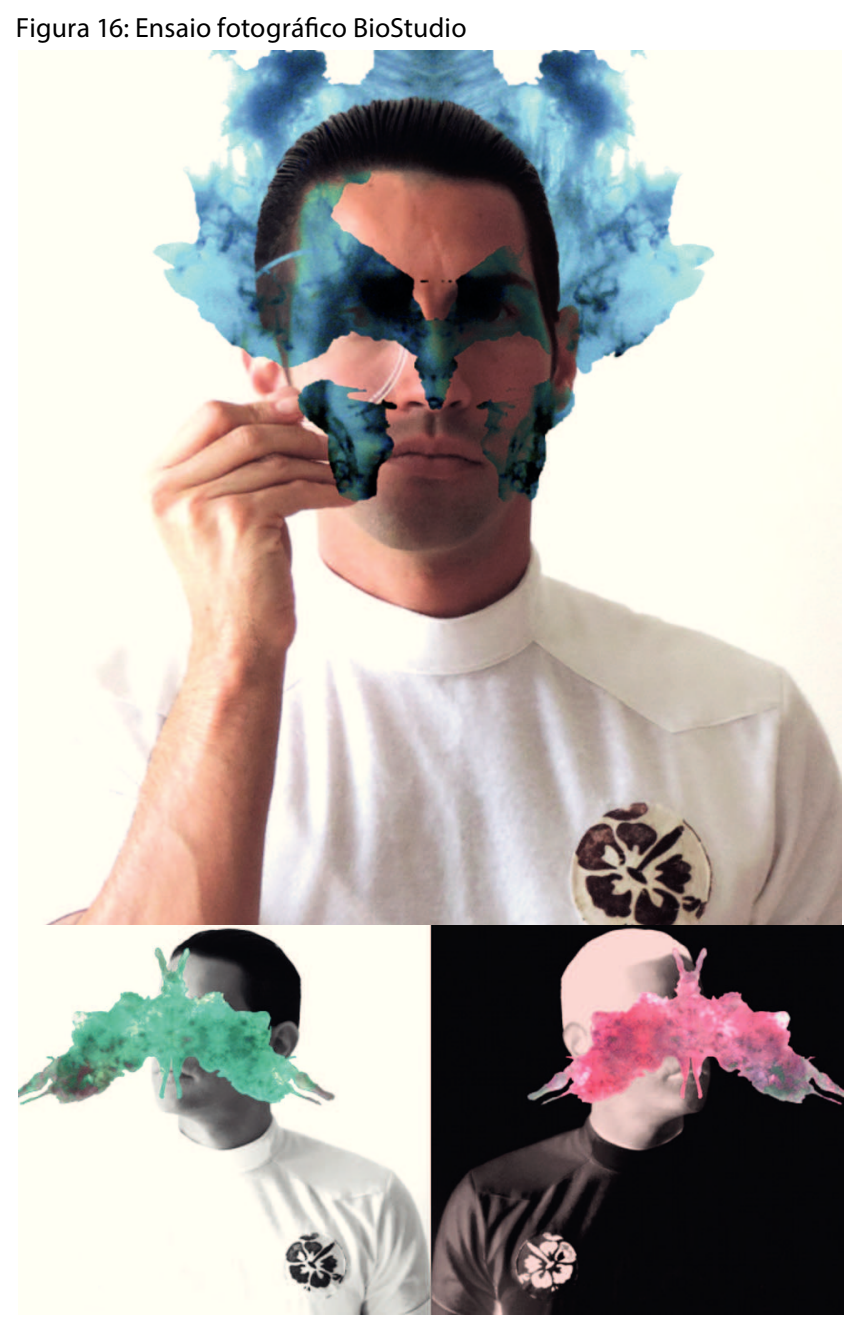

Fonte: Elaborado pelos autores.

\section{CONCLUSÕES}

Pode-se observar que a prática da utilização de seres vivos é uma alternativa possível e sutentável para a indústria textil, confirmado tanto pelos estudos de caso quanto pelos experimentos realizados, restanto ainda um intenso processo de pesquisa e investimento na área.

Foi possível verificar visualmente que a utilização das bactérias, assim como de tecidos originários de fontes alternativas apresentam uma nova estética dos produtos, mais livre e menos repetitiva e artificial, criando manchas, relevos, texturas diferenciadas, muito mais naturais e abertas ao diferente, à novidade, a surpresa.
Dos experimentos de tingimento, resumidamente, a melhor forma de tingir tecidos orgânicos utilizando bactérias foi por meio de meio líquido sob agitação, aumentando a produção de pigmento e o contato do mesmo com o tecido. Já em relação à cor, aqueles que apresentaram melhor coloração foram os isolados G27, G29 e G85. No entanto, anteriormente ao processo de lavagem é necessário um processo de fixação da cor, para que menos pigmento seja perdido. Essa fixação pode ser realizada de forma mais simples, como a lavagem com sal de cozinha, como feito tradicionalmente no Brasil há anos e de forma artesanal. Serão pensados assim, futuramente, métodos de estabilização da cor.

Em relação aos tecidos, o que obteve melhor tingimento foi o linho, muito provavelmente pela estrutura e espessura do fio que deve ter retido mais células bacterianas e absorvido mais o pigmento. Uma nova possibilidade é testar esse tipo de tingimento dessa vez em tecidos sintéticos, que normalmente incorporam e fixam melhor os pigmentos.

Outra possibilidade para projetos futuros é a extração do pigmento e tingimento dos tecidos sem necessariamente o contato com as bactérias. O processo pode tornar-se mais limpo e eficiente desta forma, assim como o pigmento extraído pode ser testado para a aplicação em tingimento de outros produtos além do têxtil, ou então como tinta para impressão em estamparia digital e serigrafia.

Vale a pena investigar também a interação entre o usuário e o produto, onde novas relações de afeto podem ser estabelecidas, e é necessário também realizar testes de usabilidade para excluir qualquer possibilidade de reações alérgicas.

Por estes e vários outros motivos, a interação entre seres vivos, tecidos e inovação, pode apresentar um futuro promissor da forma como o mundo é programado, gerido e revitalizado, em direção a uma evolução e não revolução, uma nova forma de ver a vida e estabelecer relações e experiências do vestir.

\section{REFERÊNCIAS}

ANTONELLI, P. “Vital Design”. In: MYERS, William. Bio Design. London: Thames \& Hudson, 2012.

BENYUS, J. Biomimética: Inovação Inspirada pela Natureza. São Paulo: Cultrix, 2012.

CORRÊA, G. Potencial Biotecnológico de Actinobactérias da Rizosfera de Caesalpinia pyramidalis Tul. Do Bioma Caatinga. Dissertação Mestrado 
Programa de Pós Graduação em Biotecnologia Industrial, 2014.

DUBBERLY, H. Design in the age of biology: Shifting from a mechanical-object ethos to an organic-systems ethos. Interactions magazine: v.15, n.5, 2008.

FROSCH, R.; GALLOPOULOS, N. Strategies for manufacturing. Scientific American 261(3):144-152, 1989.

LACERDA, C.; SORANSO, P.; FANGUEIRO, R. O contexto BiomiméticoAplicado ao Design de superfícies Têxteis. REDIGE: v.3, n. 03, 2012.

LASKY, J. The Beauty of Bacteria. The New York Times: pages D1-D7, January 17, 2013.

LINS, M. Seleção de actinobactérias isoladas da rizosfera da caatinga com potencial para promoção de crescimento do feijãocaupi (Vigna unguiculata (L.)Wslp.). Dissertação (Mestrado em Biotecnologia Industrial) Universidade Federal de Pernambuco, Recife, PE, 2014.

MADIGAN, M. et al. Microbiologia de Brock. Porto Alegre: Artmed, 2010.

MYERS, W. Bio Design. London: Thames \& Hudson, 2012.

SILVA, G. R. Bioprospecção de Actinobactérias Isoladas da Rizosfera de Caesalpinia pyramidalis Tul. Do Bioma Caatinga. Dissertação (Mestrado em Biotecnologia Industrial) Universidade Federal de Pernambuco, Recife, PE, 2013. 